\title{
Drying Time of Systemic and Protectant Fungicides on Coffee Leaves Exposed to Artificial Rain for the Control of Leaf Rust
}

\author{
Eduardo Granados ${ }^{1} \&$ Laércio Zambolim ${ }^{1}$ \\ ${ }^{1}$ Departamento de Fitopatologia, Universidade Federal de Viçosa, Viçosa, Minas Gerais, Brazil \\ Correspondence: Laércio Zambolim, Laboratório Proteção de Plantas, Departamento de Fitopatologia, \\ Universidade Federal de Viçosa, Viçosa 36570-900, Minas Gerais, Brazil. E-mail: Zambolim@ufv.br
}

Received: February 2, 2019

Accepted: March 13, 2019 Online Published: May 15, 2019

doi:10.5539/jas.v11n6p329

URL: https://doi.org/10.5539/jas.v11n6p329

The research is financed by Conselho Nacional de Pesquisas (CNPq); Fundação de Amparo a Pesquisa do Estado de Minas Gerais (FAPEMIG), Coordenação de Pessoal de Nivel Superior (CAPES) and Empresa Brasileira de Pesquisa Agopecuária (EMBRAPA CAFÉ).

\begin{abstract}
The drying time of pesticides on the leaves and the resistance of the deposits to rain removal are essential for success in controlling plant diseases. Because the fungicide application is performed during the rainy season, it is crucial to study the resistance of chemical deposits on the leaf surface for the control of the coffee leaf rust caused by Hemileia vastatrix. Thus, the present work analyzed the effect of an simulated rain (30 min), after several drying time of the deposits, on the removal of (i) copper oxychloride alone and associated to mineral and the adjuvant polyoxyethylene alkylphenol ether and also (ii) before several drying time, on the removal of the epoxiconazol + pyraclostrobin formulation mixed with copper hydroxide and micronutrients applied on coffee leaves, for the control of leaf rust. Around $85 \%$ and $45 \%$ of the treatments had copper retention $>30 \%$ after 120 min and $480 \mathrm{~min}$, respectively, of drying time before the rain. At $480 \mathrm{~min}$, retention of copper oxychloride + $0.75 \%$ mineral oil was $>30 \%$, whereas copper oxychloride + adjuvant polyoxyethylene alkylphenol ether at $0.05 \%$ and $0.1 \%$, respectively was $40 \%$ or higher. When copper oxychloride was added to $0.5 \%$ mineral oil at $0.05 \%$ to $0.20 \%$ of adjuvant polyoxyethylene alkylphenol ether at $480 \mathrm{~min}$ of drying time, copper retention was $>30 \%$. When copper oxychloride was added to $0.75 \%$ mineral oil, copper retention was $>30 \%$ at $0.05 \%$ and $0.10 \%$ of adjuvant polyoxyethylene alkylphenol ether. Five of the treatments with copper retention $>50 \%$ with 120 min of drying time were reduced to only two (copper oxychloride $+0.75 \%$ mineral oil; copper oxychloride $+(1.0 \%$ mineral oil $+0.1 \%$ adjuvant polyoxyethylene alkylphenol ether $)$ with copper retention $>$ $30 \%$, at the drying time of $480 \mathrm{~min}$. All the treatments differed from the control but did not differ between each other for the coffee leaf rust control. The percentage of control ranged from $94.6 \%$ to $100 \%$ and from $71.3 \%$ to $99.5 \%$ at $180 \mathrm{~min}$ and $480 \mathrm{~min}$ of drying time, respectively. Copper retention varied from $32.2 \%$ to $55.2 \%$ and from $23.7 \%$ to $51.5 \%$, at $180 \mathrm{~min}$ and $480 \mathrm{~min}$ of drying time, respectively, for the best treatments. The treatment with the highest copper retention was copper oxychloride $+0.75 \%$ mineral oil, both at 180 min and $480 \mathrm{~min}$ of drying time. The best treatments for leaf rust control were not always those with the highest copper retention by the leaves. The highest copper retention by the leaf surface was achieved with copper oxychloride mixed with $0.75 \%$ mineral oil; this treatment resulted in $>97 \%$ of coffee leaf rust control. Adding adjuvant polyoxyethylene alkylphenol ether to the mixture does not necessarily favor the tenacity and efficiency of the copper oxychloride for the coffee leaf rust control. We concluded that the copper oxychloride acts differently for the coffee leaf rust control, depending on the concentration of added mineral oil and adjuvant polyoxyethylene alkylphenol ether time zero. Pyraclostrobin + epoxiconazol alone or mixed with copper hidroxide controlled $100 \%$ of the disease after $30 \mathrm{~min}, 120 \mathrm{~min}$ and $480 \mathrm{~min}$ of spraying, but when micronutrients was added to pyraclostrobin + epoxiconazol and copper hidroxide control of coffee leaf rust reached $100 \%$ at drying time of 120 and $480 \mathrm{~min}$.
\end{abstract}

Keywords: Hemileia vastatrix, Coffea arabica, rainfastness, copper fungicides, pyraclostrobin, epoxiconazol 


\section{Introduction}

The coffee (Coffea arabica L.) leaf rust caused by Hemileia vastatrix Berkeley and Broome was first identified in 1869 attacking coffee trees in Sri Lanka (Chaves et al., 1970; Zambolim, 2016); since then, this disease has led to high losses in coffee farming. In Brazil, the disease was first identified in 1970, in the Bahia State (Chaves et al., 1970). From Brazil, rust has spread to all coffee-producing countries in the South and Central America, as well as to Mexico (McCook, 2006).

In the absence of control measures, the rust can cause losses from $35 \%$ to $50 \%$ of the Brazilian production (Zambolim, 2016). The epidemic in Central America was one of the worst in coffee-producing countries between 2010 and 2015 (Avelino et al., 2015). The damage of rust on local coffee farming in Central America, between 2012 and 2013 was estimated at 2.7 million bags, harming the region by around US $\$ 500$ million. On average, more than $50 \%$ of the coffee-growing area of Central America was affected by the disease. The incidence rates of the disease were as follows: El Salvador, 74\%; Guatemala, 70\%; Costa Rica, 64\%; Nicaragua, $37 \%$; and Honduras, 25\% (Avelino et al., 2015).

The control of coffee leaf rust in Mexico, Central American countries (Honduras, Costa Rica, El Salvador, Nicaragua, and Guatemala), and South America (Brazil, Colombia, Peru, and Ecuador) is usually performed during the rainy season. The disease attacks after the first rains and continues to develop with the progress of the rainy season until it peaks at nine to ten months, during the harvest period (Avelino et al., 2015; Zambolim, 2016).

The disease causes early leaf fall, resulting in a die-back of productive branches and fruits. Consequently, in the following year, the plants have a low fruit load (Souza et al., 2011). The most important strategy for the control of the coffee leaf rust is the use of resistant varieties. However, susceptible varieties (Catuaí, Bourbon, Caturra, and Mundo Novo) are cultivated both in Brazil and Central America, making the chemical control necessary (Zambolim, 2016).

Among the chemicals used for the control of the coffee leaf rust, protective or residual action products act to prevent the fungal penetration on the leaf surface. These include the Bordeaux mixture that has been used for over 140 years, inorganic fungicides (oxychloride, hydroxide, copper oxides and sulfates), systemic fungicides (triazoles), and strobilurins (Zambolim et al., 2008; Zambolim, 2016). Inorganic cupric fungicides were released by the chemical industry in the 1930s (Zambolim et al., 2008) and have still been used preventively for the control of coffee leaf rust (CCLR), both in years of high and low fruit load. The advantages of employing cupric fungicides for the CCLR are as follows: (i) direct toxic action to the fungal uredospore, germinative and appressory tubes on the leaf surface; (ii) providing nutrition to coffee; (iii) efficiency against other coffee diseases; (iv) preventing the emergence of resistant mutants in the H. vastatrix population since it is a fungicide with generalized action (Zambolim, 2019). Besides, since copper is a heavy metal, it does not decompose on the leaf surface, remaining active during the leaf life (Zambolim et al., 2008).

Climatic conditions are highly favorable to the disease, both in Brazil and Central American countries. Moreover, cultivated Arabica coffee varieties are highly susceptible to rust (Zambolim, 2016). Additionally, H. vastatrix has surpassed the resistance of most varieties released as resistant in Brazil, Central America and India (Zambolim, 2016). Therefore, chemical control is necessary to reduce the disease impact on coffee productivity in the short and medium-terms.

Fungicide application on leaves is a critical process in modern agriculture. Control efficiency using copper fungicides is associated with adhesion, tenacity, persistence, application technology, and anti-resistance strategies used (Mariotto et al., 1976; Santos et al., 2002; Zambolim, 2016). Retention and tenacity are influenced by physical-chemical characteristics of the leaf surface, which may be intrinsic to each cultivar (Reynolds et al., 1994). For effective control of pathogens, the amount of product that adheres to the leaf during spraying and of material remaining on the leaf after the weather action are the main factors determining the amount of active residue on the leaf surface (Rich, 1954).

Rainfall is the most critical factor to be considered regarding the removal of fungicide deposits from the leaf surface (Oliveira et al., 2002). Besides removing pesticide deposits, rain dilutes and redistributes the active ingredients (Tracker \& Young, 1999).

Several factors affect the relationship between rainfall and agrochemicals (Stefanello et al., 2016; Fife \& Nokes, 2002; Wang \& Liu, 2007). The most important include the intensity and amount of rainfall, interval between application and rainfall, commercial formulation of fungicides, product solubility in water, and leaf characteristics of the plant variety (Cabras et al., 2001; Green, 2001; Capucho et al., 2013a). Adjuvants are 
usually employed to provide better adhesion to the leaf surface and increase tenacity under rainfall (Suheri \& Latin, 1991).

According to Underwood (2000), adjuvants are substances with no fungitoxic effect, but that increase the application efficiency when added to the pesticide mixture, by increasing the biological activity of the active ingredient and reducing the effects of the drift and losses by rain and the worker's exposure to the pesticide and environmental contamination (Tu \& Randall, 2003).

Studies have shown that the adverse effect of rain is directly related to the interval between pesticide application and its occurrence (Stefanello et al., 2016). Debortoli (2008) showed that simulated rain affected the control of Asian soybean rust negatively, especially when no adjuvant was used mixed with the fungicide. According to this author, the occurrence of rain up to 30 minutes after applying the treatment had a great influence on the effective control of the disease.

Emulsifiable oils can increase the penetration rate through the cuticle wax layer in plant species with waxy surfaces like coffee, citrus, cruciferous, and bananas (Witt, 2001). Oil addition to the fungicides has provided efficient disease control, even when dealing with systemic fungicides (Bonelli et al., 2005; Antuniassi et al., 2005). Residual analysis of flutriafol showed that soybean leaves treated with mineral oil had a higher concentration of the active ingredient of this systemic fungicide in their tissues. Mineral oil is indicated mainly as an adhesive and can also alter the spectrum of spray drops due to its highly viscosity (Christofoletti, 1999).

Avoiding the emergence of fungicide resistance in the population of phytopathogenic fungi remains a significant challenge in coffee cultivation (Staub \& Sozzi, 1984; Zambolim, 2016). Therefore, multi-site (cupric) protective fungicides should always be used mixed or alternated with systemic fungicides for disease control, to minimize or even eliminate the risk of emerging resistant mutants in the H. vastatrix population (Chalfoun \& Carvalho,1999; Zambolim, 2016; Souza et al., 2011).

The emergence of systemic fungicides in the 1980s revolutionized agriculture. This is especially true for the triazoles group, whose systemicity provides more advanced options for effective CCLR and is, therefore, a critical tool for the global coffee industry (Garcia, 1999). Fungicides from the triazol and strobilurin groups have been very useful to control coffee diseases in the last ten years. Demethilation inhibitor fungicide (DMI) reduces ergosterol biosynthesis (Koller \& Scheinplug, 1987). The mixture of the two fungicide groups, when used for the coffee leaf rust control, hinders the emergence of resistant mutants in the population of $H$. vastatrix since triazols are demethylation inhibitors and strobilurins (extracellular quinone-QoI-inhibitor act on the complex III of the mitochondrial electron transport chain, preventing the ATP production) (Bartlet, 2002). It is worth mentioning that the formulation of the two fungicide groups (triazole + strobilurin) are more efficient than the products alone (Zambolim, 2016).

The triazole fungicides are recommended based on the disease incidence and/or weather conditions and the pending fruit load (Souza et al., 2011). In years of high pending fruit load, the first disease signs are observed on the underside of the coffee leaf in November/December, reaching the highest peaks in June/July in Brazil. The application interval usually varies between 60 and 75 days (Souza et al., 2011; Zambolim, 2016). However, since in Brazil the applications are performed in the rainy season (December to March/April), there is always the possibility of the removal of deposited products to the extent of threatening the coffee control leaf rust. The penetration time of the systemic fungicides (triazoles) in the leaf tissues is crucial in disease control and varies according to several factors; however, it ranges usually from 30 minutes to two hours in coffee plants (Zambolim, 2016).

The control of coffee diseases should always be integrated, aiming at rust and other important diseases, including bacterial blight, Phoma leaf spot, Ascochyta leaf spot and brown eye spot. Thus, it is imperative to adopt anti-resistance strategies aimed at preventing the emergence of resistant mutants in the pathogen population. In addition the integrated control also aims to correct nutritional deficiencies of microelements like zinc, copper, boron and even manganese, which are essential to coffee. Therefore, studies of product mixtures that are used in the coffee crops, like the triazol, strobilurin, and cupric fungicides, besides the boron and zinc micronutrients, are relevant.

The deposits left by cupric fungicides on the leaf surface can be removed by rain. Few reports showed that adjuvants added to cupric fungicide can increase copper retention in the high rainfall season. The effect of rain on the removal of triazole residues formulated with strobilurin, cupric fungicide, and micronutrients for the control of coffee leaf rust, after several drying times of the deposits, is also not yet known in the literature. For these reasons the objective of this study was to evaluate the effect of simulated rain on the removal of deposits of pesticides coffee leaves to control of coffee leaf rust. 


\section{Material and Methods}

\subsection{Study Area}

\subsubsection{Source of Plant Material and Inoculum of the Pathogen}

In the tests, Coffea arabica leaves of the Caturra variety were used due to their high susceptibility to H. vastatrix (Zambolim, 2016). They were left growing in a greenhouse and were fertilized with macro and micronutrients at every 30 days. The leaves used in the experiments, well-developed and with no symptoms of nutritional deficiencies, were taken from the third pair of the branches.

Uredospores of the $H$. vastatrix race II, with germination rate $>45 \%$, were used in the experiment. They were taken from the collection of the Departmento de Fitopatologia da Universidade Federal de Viçosa, Viçosa, Minas Gerais, Brazil. The uredospores were inoculated on Coffea arabica leaves of the Caturra variety at three months old, using a 2 camel's hairbrush. Approximately $1 \mathrm{mg}$ of uredospores were deposited on each leaf. Two well-developed leaves of each plant were inoculated.

The plants were incubated for $72 \mathrm{~h}$ in a humid chamber $\left(22^{\circ} \mathrm{C}\right.$ and relative humidity $100 \%$ and then transferred to an incubation chamber also at $22{ }^{\circ} \mathrm{C}$, where they remained for 45 days to produce uredospores. The sampling was performed by scraping the spores of the pustules with a scalpel. Subsequently, the spores were homogenized in 125 -mesh sieve and stored in gelatin capsules (100 mg per capsule) in a $50 \mathrm{~mL}$ beaker, which was placed in a desiccator at $5{ }^{\circ} \mathrm{C}$ with $50 \%$ of relative humidity (Zambolim \& Chaves, 1974). Part of the uredospores was stored in an ultrafreezer at $-80{ }^{\circ} \mathrm{C}$.

Uredospore germination tests were performed on plastic plates containing $1 \%$ water agar. The uredospores were spread on the agar layer with a 2 camel's hairbrush, and soon after they were placed in a dark room for $24 \mathrm{~h}$ at $22^{\circ} \mathrm{C}$. The counts of germinated and non-germinated uredospores were made under a stereoscopic microscope. Those in which the germinative tube reached twice the diameter were considered as the ones that had germinated.

\subsubsection{Inoculation Procedure}

After the coffee leaves were exposed to a $30 \mathrm{~mm}$ rainfall, an interval of 15 minutes was given for air drying before removing the leaf discs. Four $1.5 \mathrm{~cm}$ diameter discs were removed from the central region of each atomized leaf of with a corkscrew. They were then inoculated according to the time after the simulated rainfall.

The inoculation was made in the abaxial surface of each leaf by spreading $1 \mathrm{mg}$ of uredospores with germination rate $>45 \%$, using a 2 camel's hairbrush (Eskes, 1982). Subsequently, the discs were deposited with the abaxial face upwards, on stainless steel screens inside plastic boxes $(12 \mathrm{~cm} \times 12 \mathrm{~cm} \times 3.0 \mathrm{~cm})$, and sprinkled with sterile distilled water. The plastic boxes were incubated in a dark growth chamber for $48 \mathrm{~h}$ at $22 \pm 2{ }^{\circ} \mathrm{C}$. Finally, they were taken to an incubation chamber with a photoperiod of $12 \mathrm{~h}$ (light/dark) and temperature controlled at $22 \pm 2{ }^{\circ} \mathrm{C}$, where they remained for 45 days until the final analysis of the presence of uredospores.

Analysis of the copper retention rate on leaves: The copper rate on leaves was used to determine its retention with and without rainfall, according to the following equation,

$$
\text { Copper Retention }-\mathrm{CuR}(\%) \mathrm{n}=\mathrm{LWR} / \mathrm{LNR} \times 100
$$

where,

$\mathrm{LWR}=$ detached coffee leaves sprayed with pesticides and with rainfall simulation; LNR $=$ detached coffee leaves sprayed with pesticides and without rainfall simulation.

\subsubsection{Determination of the Control of Coffee Leaf Rust (CCLR) Rate}

The determination of the CCLR rate was calculated using the following equation (Souza et al., 2011),

$$
\text { CCLR rate }(\%)=(\mathrm{MC}-\mathrm{VG}) / \mathrm{MC} \times 100
$$

where, $\mathrm{MC}=$ mean control value; $\mathrm{VG}=$ real value per leaf.

For the CCLR rate, a non-spray negative control was used, which was subtracted from the treatments and was not considered to calculate the variables.

\subsection{Chemicals Employed in the Experiments}

The chemical products employed in the experiments were as follows: copper oxychloride (copoxy) (Recop ${ }^{\mathrm{R}} 84 \%$ $\mathrm{m} / \mathrm{m}$, WP, $3.0 \mathrm{Kg} \mathrm{ha}^{-1}$ ); copper hydroxide (cophi) $\left(\right.$ Supera $\left.^{\mathrm{R}} 750 \mathrm{SC}, 2.5 \mathrm{~L} \mathrm{ha}^{-1}\right)$; pyraclostrobin $133 \mathrm{~g} / \mathrm{L}+$ epoxiconazole $50 \mathrm{~g} / \mathrm{L}$ (pyepox) (Opera $\left.{ }^{\mathrm{R}} \mathrm{SE}, 1.5 \mathrm{~L} \mathrm{ha}^{-1}\right)$; boric acid (ba) $\left(2.0 \mathrm{~g} \mathrm{~L}^{-1}\right)$; zinc sulfate (zs) $\left(4.0 \mathrm{~g} \mathrm{~L}^{-1}\right)$; 
mineral oil (mo) $\left(\right.$ Assit $\left.^{\mathrm{R}}\right)$ at $0.25 \%, 0.50 \%, 0.75 \%$, and $1.0 \%$; polyoxyethylene alkylphenol ether (adj) (Haiten ${ }^{\mathrm{R}}$ $20 \% \mathrm{~m} / \mathrm{V}$ ) at $0.05 \%, 0.1 \%$, and $0.2 \%$.

The different concentrations of the chemicals were prepared for a final volume of $500 \mathrm{~mL}$, based on the commercial dose (AGROFIT, 2019). They were sprayed onto Coffea arabica leaves of the Caturra variety using a DeVilbiss Model 15 atomizer driven by an electric compressor, aiming to spray the same volume of the mixture for each leaf group of each replicate. The spraying was performed on the abaxial face of detached leaves, on a platform designed to receive showers of rain in the greenhouse.

\subsection{Rainfall Simulation}

A rainfall simulator, specially designed to represent all the parameters and configurations of conventional terrestrial equipment was used in this study (Figure 1). This equipment enables the simulating rainfall slides by using special spray tips with flat jet and thick droplets. The equipment was calibrated to provide a rainfall of 30 $\mathrm{mm}$ (Silva et al., 2014; Perreira et al., 2017). The application of the pesticides was performed at night (no sunlight) with temperature ranging between $20{ }^{\circ} \mathrm{C}$ and $22{ }^{\circ} \mathrm{C}$ and $55 \%$ of relative humidity. A $30 \mathrm{~mm}$ rainfall was artificial after $120 \mathrm{~min}$ and $480 \mathrm{~min}$ of spraying the chemicals. Leaves sprayed with treatments, and that did not receive simulated rain were used as the control. Some leaves were taken to the laboratory for analysis to determine the copper concentration in the leaf tissue.

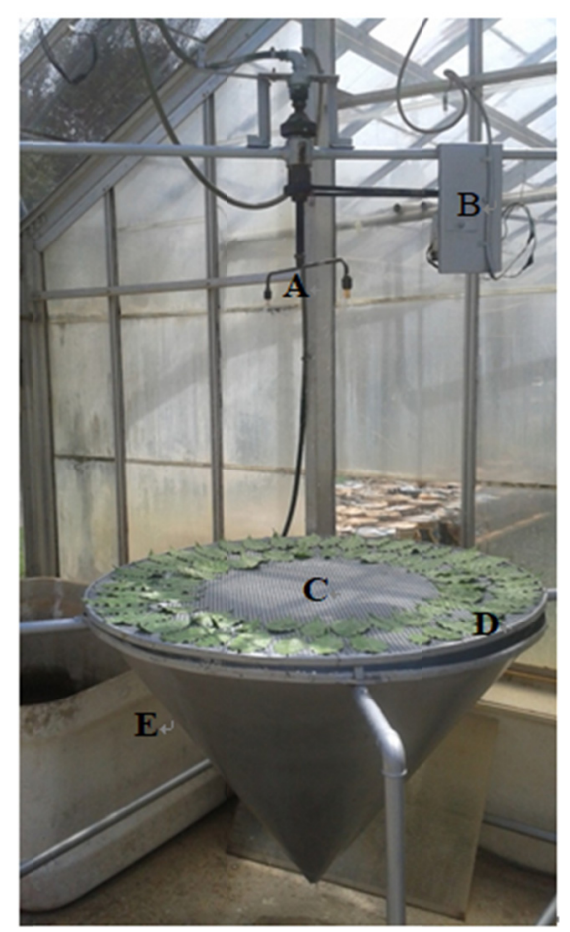

Figure 1. Rainfall simulator used in the experiment. (A) Rainfall simulation nozzles. (B) Nozzle speed control and adjustment. (C) Spray table. (D) Coffee leaves. (E) Water reservoir and pressure control

\subsection{Data Collection Procedures}

During the experiment, rust severity was evaluated on leaf discs, starting on the $18^{\text {th }}$ day and ending on the $45^{\text {th }}$ day after inoculating the uredospores into the 16 discs of each plastic box. The scale of the rust severity was previously determined, as follows: 0 , no signs of spores on the discs; 1 ) $\leq 10 \%$; $)>10 \%$ and $\leq 15 \%$; 3 ) $>15 \%$ and $\leq 30 \% ; 4)>30 \%$ and $\leq 50 \%$; and 5$)>50 \%$. The calculated response variables were the rust severity based on the described scale and the area under the disease progress curve (AUDPC) (Campbell \& Madden, 1990) based on severity data.

\subsection{Data Analysis}

For statistical analysis, the InfoStat computer program (Di Rienzo et al., 2015) was used after the data were transformed in to $\sqrt{\mathrm{x}+1}$. Mean comparison analysis was performed using the Tukey test at $5 \%$ of significance. 
This work was divided into three experiments.

Experiment 1: Drying time of copper associated with mineral oil and the adjuvant polyoxyethylene alkylphenol ether on coffee leaves, after rainfall for the control of coffee leaf rust.

The experiment consisted of 20 treatments. The experimental design was completely randomized with three replicates, each represented by a plastic box with 16 discs of Coffea arabica leaves of the Caturra variety.

The test was conducted to select treatments that had copper retention by the leaf surface higher than or equal to $30 \%$ at two drying time (120 min and $480 \mathrm{~min}$ ) after a $30 \mathrm{~mm}$ artificial rain, added or not to mineral oil and adjuvant. The treatments employed are shown in Table 1.

Table 1. Treatments employed to study the effect of copper oxychloride associated or not with mineral oil and adjuvant on the control of coffee leaf rust

\begin{tabular}{|c|c|c|c|c|c|c|c|c|}
\hline \multirow{2}{*}{ Treatments } & \multirow{2}{*}{$\begin{array}{l}\text { Copper oxychloride }(\mathrm{Kg} / \mathrm{ha}) \\
3.0\end{array}$} & \multicolumn{4}{|c|}{ Mineral oil (\%) } & \multicolumn{3}{|c|}{ Adjuvant* (\%) } \\
\hline & & 0.25 & 0.50 & 0.75 & 1.0 & 0.05 & 0.10 & 0.20 \\
\hline 1 & $\mathrm{X}^{1}$ & - & - & - & - & - & - & - \\
\hline 2 & $\mathrm{X}$ & $\mathrm{X}$ & - & - & - & - & - & - \\
\hline 3 & $\mathrm{X}$ & - & $\mathrm{X}$ & - & - & - & - & - \\
\hline 4 & $\mathrm{X}$ & - & - & $\mathrm{X}$ & - & - & - & - \\
\hline 5 & $\mathrm{X}$ & - & - & - & $\mathrm{X}$ & - & - & - \\
\hline 6 & $\mathrm{X}$ & - & - & - & - & $\mathrm{X}$ & - & - \\
\hline 7 & $\mathrm{X}$ & - & - & - & - & - & $\mathrm{X}$ & - \\
\hline 8 & $\mathrm{X}$ & - & - & - & - & - & - & $\mathrm{X}$ \\
\hline 9 & $\mathrm{X}$ & $\mathrm{X}$ & - & - & - & $\mathrm{X}$ & - & - \\
\hline 10 & $\mathrm{X}$ & $\mathrm{X}$ & - & - & - & - & $\mathrm{X}$ & - \\
\hline 11 & $\mathrm{X}$ & $\mathrm{X}$ & - & - & - & - & - & $\mathrm{X}$ \\
\hline 12 & $X$ & - & $X$ & - & - & $X$ & - & - \\
\hline 13 & $X$ & - & $X$ & - & - & - & $X$ & - \\
\hline 14 & X & - & X & - & - & - & - & $X$ \\
\hline 15 & $X$ & - & - & $X$ & - & $X$ & - & - \\
\hline 16 & X & - & - & $X$ & - & - & X & - \\
\hline 17 & $X$ & - & - & $X$ & - & - & - & $X$ \\
\hline 18 & $X$ & - & - & - & $X$ & $X$ & - & - \\
\hline 19 & $X$ & - & - & - & $X$ & - & $X$ & - \\
\hline 20 & $X$ & - & - & - & $X$ & - & - & $X$ \\
\hline
\end{tabular}

Note. *Polioxietilene Alquil Fenol Éther; ${ }^{1}$ Means that the chemical took part of the treatment.

Experiment 2: Drying time of copper oxichloride higher than or equal to $30 \%$, mixed with mineral oil and polyoxyethylene alkylphenol ether on coffee leaves exposed to rain, for the control of coffee leaf rust.

The experiment consisted of nine treatments. The experimental design was completely randomized with three replicates, each represented by a plastic box with 16 discs of Coffea arabica leaves of the Caturra variety. The treatments selected for the Experiment 2 were those with copper retention by the leaf surface higher than or equal to $30 \%$ from the Experiment 1 . The following treatments were selected: 1 . Copper oxychloride (copoxy); 2. Copoxy $+0.75 \%$ mineral oil (mo); 3 . Copoxy $+0.05 \%$ adj; 4 . Copoxy $+0.5 \%$ mo $+0.05 \%$ polyoxyethylene alkylphenol ether (adj); 5 . Copoxy $+0.5 \%$ mo $+0.1 \%$ adj; 6 . Copoxy $+0.5 \%$ mo $+0.2 \%$ adj; 7 . Copoxy + $0.75 \%$ mo $+0.05 \%$ adj; 8 . Copoxy $+1.0 \%$ mo $+0.1 \%$ adj; 9 . Control (water). The drying time of the chemical deposits on coffee leaves before the $30 \mathrm{~mm}$ artificial rainfall was $120 \mathrm{~min}$ and $480 \mathrm{~min}$, respectively.

Experiment 3: Effect of pyraclostrobin + epoxiconazole + copper hydroxide + boric acid + zinc sulfate in a mix or alone, after the $30 \mathrm{~mm}$ simulated rainfall, for the coffee leaf rust control.

The experiment consisted of nine treatments. The experimental design was completely randomized with three replicates, each represented by a plastic box with 16 discs of Coffea arabica leaves of the Caturra variety.

The following treatments were included in the experiment: 1. Control (water); 2. Zinc sulfate (zs) + boric acid (ba); 3. Copper hydroxide (coophi) 4. Coophi + zs + ba; 5. Pyraclostrobin + epoxyconazol (pyepox); 6. Pyepox + zs + ba; 7. Pyepox + coophi; 8. Pyepox + coophi + zs + ba. 


\section{Results}

All experiments were repeated at least once. Thus, we chose to present an experiment that represented all the others. The results will be presented in three experiments.

Experiment 1: Drying time of copper associated with mineral oil and the adjuvant polyoxyethylene alkylphenol ether on coffee leaves, after rainfall for the control of coffee leaf rust.

The results of the different treatments of the copoxy, mo and adj mixture at different concentrations are shown in Figures $2 \mathrm{~A}$ and $2 \mathrm{~B}$. This experiment was designed aiming to know the treatments with copper retention rates equal to or higher than $30 \%$ by the leaf surface.
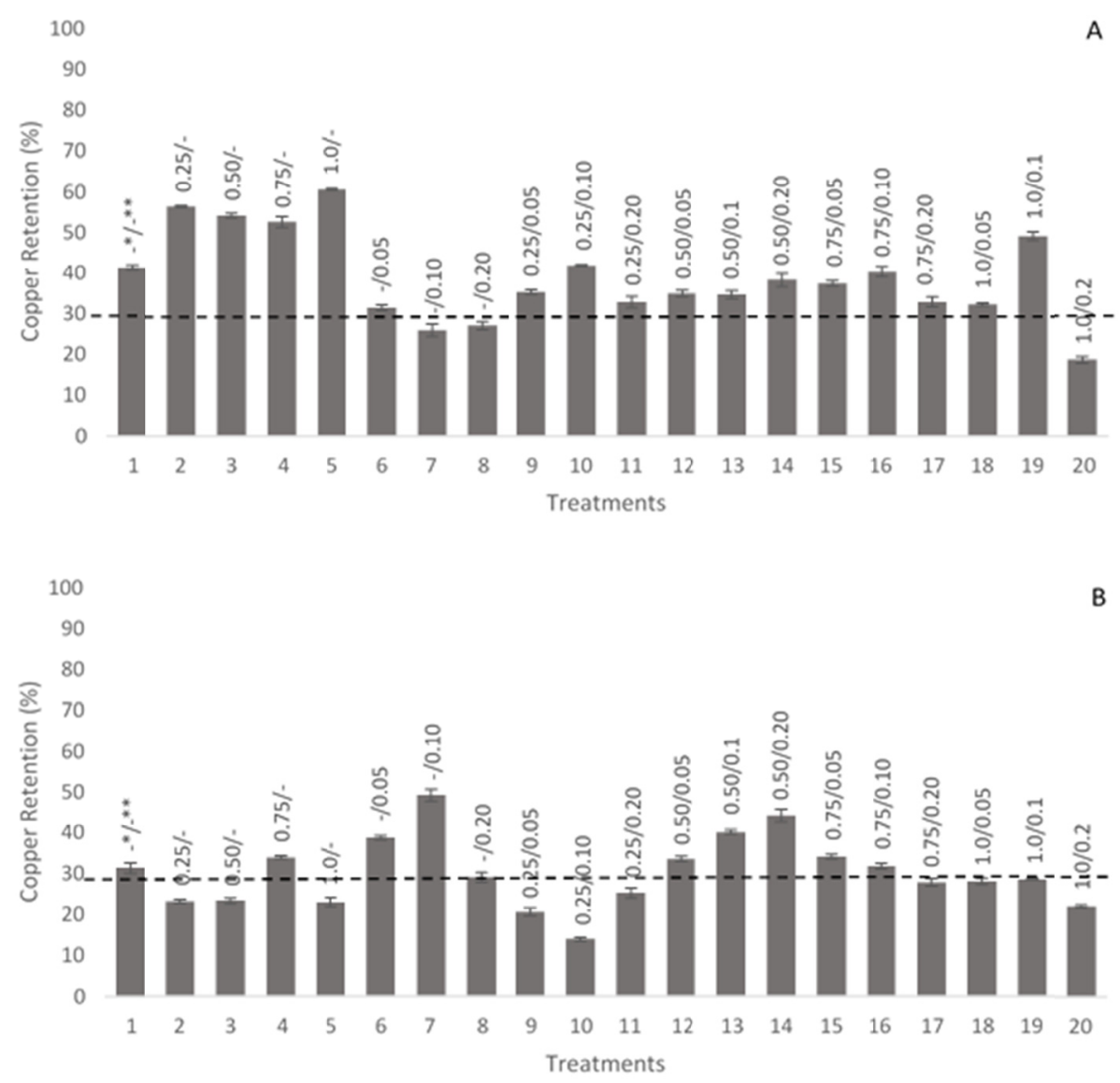

Figure 2. Retention of copper submitted to simulated rain of $30 \mathrm{~mm}, 120$ (A) and 480 (B) minutes after spraying of copper oxychloride $\left(3.0 \mathrm{~kg} / \mathrm{ha}^{-1}\right)$ alone and associated with mineral oil and polioxietilene alquil fenol éther at diferent concentrations

Note. *\% Mineral oil; ** Adjuvant polioxietileno alquil fenol ether.

Treatments with different mixtures of copoxy + mo + adj had a mean copper retention rate higher than $30 \%$. At 120 min, 17 treatments (85\%) had copper retention rate higher than 30\% (Figure 2A). The treatments 7, 8 and 20 (copoxy mixed with ad at $0.10 \%$ and $0.20 \%$, respectively) had lower copper retention rates, between $15 \%$ and $20 \%$ (Figure 2A). The treatments with copper retention rates equal to or above $50 \%$ were the mix of copoxy with mo only, at all the concentrations evaluated $(0.25 \%, 0.5 \%, 0.75 \%$, and $1.0 \%)$, respectively.

When the $30 \mathrm{~mm}$ artificial rain was simulated at $480 \mathrm{~min}$ of drying time after spraying (Figure 2B), only $50 \%$ of treatments had copper retention rate equal or higher than $30 \%$. Treatments 2,3 , and 5 with copoxy + mo at $0.25 \%, 0.5 \%$, and $1.0 \%$ respectively, and treatments $9,10,11,17,18,19$, and 20 with copoxy + mo + adj at $(0.25 \%+0.05 \%),(0.25 \%+0.10 \%),(0.25 \%+0.20 \%),(0.75 \%+0.20 \%),(1.0 \%+0.05 \%),(1.0 \%+0.10 \%)$, and $(1.0 \%+0.20) \%$, respectively, had copper retention rates below $30 \%$. 
The copoxy treatments associated with mo + adj $(9,10$, and 11$)$ at $(0.25 \%+0.05 \%),(0.25 \%+0.10 \%)$ and $(1.0 \%$ $+0.20 \%$, respectively, had copper retention rates from $15 \%$ to $20 \%$. Only treatments $6,7,13$ and $14(0.0 \%+$ $0.05 \%),(0.0 \%+0.10 \%),(0.5 \%+0.10 \%)$ and $(0.5 \%+0.20 \%)$, respectively, had values $>40 \%$.

Treatment 5 (copoxy $+1.0 \% \mathrm{mo}$ ) reached $60 \%$ of copper retention when exposed to the $30 \mathrm{~mm}$ rain, at $120 \mathrm{~min}$ after spraying. After $480 \mathrm{~min}$, treatment 7 (copoxy $+0.10 \%$ adj) had $50 \%$ of copper retention.

Based on the results above, we selected the treatments with copper retention equal to or higher than $30 \%$ after exposure to the $30 \mathrm{~mm}$ rain, at $120 \mathrm{~min}$ and $480 \mathrm{~min}$ of drying time of chemicals on coffee leaves, to be evaluated in Experiment 2.

Experiment 2: Drying time of copper oxichloride higher than or equal to $30 \%$, mixed with mineral oil and polyoxyethylene alkylphenol ether on coffee leaves exposed to rain, for the control of coffee leaf rust.

The eight treatments selected from Experiment 1 consisted of $3.0 \mathrm{~kg} \mathrm{ha}^{-1}$ copoxy (commercial product), with or without mineral oil or adjuvant (Table 2$)$. There were significant differences $(\mathrm{P}<0.05)$ between the results from treatments with the application of chemicals and the control for area under disease progress curve (AUDPC), considering the drying time of $120 \mathrm{~min}$. (Table 2). On the other hand, there were no significant differences (P $<$ 0.05 ) between the treatments with the application of chemical products. However, the severity level (AUDPC) ranged from 1.4 (treatment 6) to 20.2 (treatment 3); rates in treatment 9 (control) reached 317.6. The maximum severity level of the disease was 20.2 for treatment 3 , and the minimum was 0.0 for treatment 4 . The control rate ranged from $94.6 \%$ (treatment 3 ) to $100 \%$ (treatment 4). Treatment 2 had the highest value of copper retention by the leaf surface, $55.2 \%$, which was equivalent to the treatment 7 but differed from the other treatments. All other treatments did not differ significantly and varied from $32.8 \%$ (treatment 5) to $39.9 \%$ (treatment 7).

Table 2. Effect of drying time (120 min and $480 \mathrm{~min}$ ) of copper fungicide mixed with mineral oil and adjuvant on coffee leaves exposed to $30 \mathrm{~mm}$ of artificial rain, for the control of coffee leaf rust

\begin{tabular}{|c|c|c|c|c|c|c|}
\hline \multirow{3}{*}{ Treatments } & \multicolumn{6}{|c|}{ Drying time of the deposits after spraying } \\
\hline & \multicolumn{3}{|c|}{$120 \mathrm{~min}$} & \multicolumn{3}{|c|}{$480 \mathrm{~min}$} \\
\hline & AUDPC $^{1}$ & Rust control (\%) & Copper retention $(\%)$ & $\mathrm{AUDPC}^{1}$ & Rust control (\%) & Copper retention $(\%)$ \\
\hline 1 & $11.4 \mathrm{~b}$ & $96.9 \mathrm{a}$ & $33.2 \mathrm{~b}$ & $66.3 \mathrm{~b}$ & $71.5 b$ & $36.8 \mathrm{abc}$ \\
\hline 2 & $10.9 \mathrm{~b}$ & $97.0 \mathrm{a}$ & $55.2 \mathrm{a}$ & $2.9 \mathrm{c}$ & $98.5 \mathrm{a}$ & $51.5 \mathrm{a}$ \\
\hline 3 & $20.2 b$ & $94.6 \mathrm{a}$ & $33.2 b$ & $44.2 \mathrm{~b}$ & $77.1 \mathrm{~b}$ & $31.1 \mathrm{bc}$ \\
\hline 4 & $0.0 \mathrm{~b}$ & $100.0 \mathrm{a}$ & $36.4 b$ & $5.8 \mathrm{c}$ & $97.3 \mathrm{a}$ & $30.1 \mathrm{bc}$ \\
\hline 5 & $6.2 b$ & $98.3 \mathrm{a}$ & $32.8 b$ & $0.7 \mathrm{c}$ & $99.5 \mathrm{a}$ & $27.1 \mathrm{bc}$ \\
\hline 6 & $1.4 \mathrm{~b}$ & $99.6 \mathrm{a}$ & $37.5 \mathrm{~b}$ & $3.9 \mathrm{c}$ & $97.9 \mathrm{a}$ & $23.7 \mathrm{c}$ \\
\hline 7 & $7.9 \mathrm{~b}$ & $97.7 \mathrm{a}$ & $39.9 \mathrm{ab}$ & $1.2 \mathrm{c}$ & $99.2 \mathrm{a}$ & $38.8 \mathrm{ab}$ \\
\hline 8 & $10.2 b$ & $97.2 \mathrm{a}$ & $36.5 b$ & $1.4 \mathrm{c}$ & $99.1 \mathrm{a}$ & $29.7 \mathrm{bc}$ \\
\hline 9 & $317.6 \mathrm{a}$ & - & - & $2018.4 \mathrm{a}$ & - & - \\
\hline $\mathrm{CV}^{2}(\%)$ & 8.6 & 2.2 & 3.7 & 7.8 & 5.9 & 3.9 \\
\hline
\end{tabular}

Note. ${ }^{1}$ Area Under Disease Progress Curve (AUDPC); ${ }^{2}$ Coefficient of variation.

Mean values followed by the same letter across columns did not show significant differences (Tukey test, $\mathrm{P}<$ $0.05)$.

Treatments: 1 . Copoxy; 2. Copoxy $+0.75 \%$ mo; 3. Copoxy $+0.05 \%$ adj; 4 . Copoxy $+0.5 \%$ mo $+0.05 \%$ adj; 5 . Copoxy $+0.5 \%$ mo $+0.10 \%$ adj; 6 . Copoxy $+0.5 \%$ mo + adj $0.20 \% ; 7$. Copoxy $+0.75 \%$ mo $+0.05 \%$ adj; 8 . Copoxy $+1.0 \%$ mo $+0.10 \%$ adj; 9 . Control (water).

There was some variation in the severity level (AUDPC) between treatments with 480 min of drying time after treatments (Table 2) and $30 \mathrm{~mm}$ of artificial rain. All treatments with chemicals differed significantly from the control. Except for treatments 1 and 3, which had a severity level $>44.2$, all the other treatments $(2,4,5,6,7$ and 8 ) matched each other, with severity rates varying from 1.2 to 5.8. The rate of coffee leaf rust control ranged from $77.5 \%$ (treatment 1 ) to $99.5 \%$ (treatment 5). Treatments 1 and 3 produced similar results and differed from the others, with the lowest values of coffee leaf rust control $(71.5 \%$ to $77.1 \%)$. The other treatments $(2,4,5,6,7$, 8 ) were equivalent and resulted in the highest rates of coffee leaf rust control $(97.3 \%$ to $99.5 \%)$. There was a significant variation between treatments regarding copper retention with treatments 6 and 2 showing the lowest $(23.7 \%)$ and the highest $51.5 \%$ values, respectively. 
Table 3 shows the correlation data for severity (\%), AUDPC, coffee leaf rust control (\%) and copper retention by the leaf surface. Higher rates of copper retention by leaf surfaces corresponding to a higher rate of CCLR reflected in both the severity rate and AUDPC values.

Table 3. Correlation coefficient of the variables studied

\begin{tabular}{|c|c|c|c|c|}
\hline & Severity (\%) & AUDPC $^{1}$ & Rust Control (\%) & Copper Retention (\%) \\
\hline Severity (\%) & 1 & & & \\
\hline $\mathrm{AUDPC}^{1}$ & 0.98 & 1 & & \\
\hline Rust control (\%) & -0.94 & -0.89 & 1 & \\
\hline Copper retention (\%) & -0.06 & -0.04 & 0.06 & 1 \\
\hline
\end{tabular}

Note. ${ }^{1}$ Area Under Disease Progress Curve.

Experiment 3: Effect of pyraclostrobin + epoxiconazole + copper hydroxide + boric acid + zinc sulfate in a mix or alone, after the $30 \mathrm{~mm}$ simulated rainfall, for the coffee leaf rust control.

In this experiment, a formulation containing a triazol fungicide (epoxiconazol) and a fungicide of the strobilurin group (pyraclostrobin) was studied to evaluate their effect in association with cupric fungicide and micronutrients on the control of coffee leaf rust. This mixture was applied to leaves that were exposed to $30 \mathrm{~mm}$ of artificial rain and were subjected to different drying time of the deposits for the coffee leaf rust control.

The treatments were compared within each period group, because the interaction of the treatment variables and time in minutes of application of the artificial rain after application of the chemicals was significant $(\mathrm{P}<0.05)$ (Table 4). The effect of the treatments for time zero, $30 \mathrm{~min}, 120 \mathrm{~min}$, and $480 \mathrm{~min}$ after application of the chemicals resulted in different rates of control of coffee leaf rust. At time zero, control of coffee leaf rust reached $100 \%$ in treatments 5, 6 and 8, with the application of pyepox, except when boric acid and zinc sulfate were added to this mixture (treatment 7). However, at $30 \mathrm{~min}, 120 \mathrm{~min}$, and $480 \mathrm{~min}$ after application, rates of control of coffee leaf rust in the treatments that included pyepox also reached $100 \%$.

Treatments with coophi were $100 \%$ efficient for control of coffee leaf rust at 120 min and 480 min after the rain simulation, regarding both disease severity and AUDPC. The treatments with the application of boric acid and zinc sulphate did not differ significantly $(\mathrm{P}<0.05)$ from the control (no chemicals) and therefore they were considered inefficient.

Table 4. Effect of chemicals applied at different times (min) after simulating $30 \mathrm{~mm}$ rain on coffee leaf rust severity (Sev.) and area under disease progress curve (AUDPC)

\begin{tabular}{|c|c|c|c|c|c|c|c|c|}
\hline \multirow{2}{*}{ Treatments } & \multicolumn{2}{|c|}{ Zero } & \multicolumn{2}{|c|}{30} & \multicolumn{2}{|c|}{120} & \multicolumn{2}{|c|}{480} \\
\hline & Sev. & AUDPC & Sev. & AUDPC & Sev. & AUDPC & Sev. & AUDPC \\
\hline 1. & $5.2 \mathrm{a}$ & $145.3 \mathrm{a}$ & $2.4 a$ & $68.8 \mathrm{a}$ & $12.4 \mathrm{a}$ & $350.2 \mathrm{a}$ & $12.0 \mathrm{a}$ & $339.6 a$ \\
\hline 2. & $3.6 \mathrm{a}$ & $101.8 \mathrm{a}$ & $1.9 \mathrm{ab}$ & $55.2 \mathrm{a}$ & $7.4 \mathrm{~b}$ & $207.2 b$ & $7.3 \mathrm{~b}$ & $206.7 b$ \\
\hline 3. & $2.5 \mathrm{ab}$ & $69.8 \mathrm{ab}$ & $0.1 \mathrm{bc}$ & $3.7 \mathrm{~b}$ & $0.0 \mathrm{c}$ & $0.0 \mathrm{c}$ & $0.1 \mathrm{c}$ & $1.6 \mathrm{c}$ \\
\hline 4. & $2.2 \mathrm{abc}$ & $60.8 \mathrm{ab}$ & $0.0 \mathrm{c}$ & $0.0 \mathrm{~b}$ & $0.1 \mathrm{c}$ & $1.6 \mathrm{c}$ & $0.0 \mathrm{c}$ & $0.0 \mathrm{c}$ \\
\hline 5. & $0.0 c$ & $0.0 c$ & $0.0 c$ & $0.0 b$ & $0.0 c$ & $0.0 \mathrm{c}$ & $0.0 \mathrm{c}$ & $0.0 c$ \\
\hline 6. & $0.0 \mathrm{c}$ & $0.0 \mathrm{c}$ & $0.0 \mathrm{c}$ & $0.0 \mathrm{~b}$ & $0.0 \mathrm{c}$ & $0.0 \mathrm{c}$ & $0.0 \mathrm{c}$ & $0.0 \mathrm{c}$ \\
\hline 7. & $0.9 b c$ & $26.2 b c$ & $0.0 \mathrm{c}$ & $0.0 \mathrm{~b}$ & $0.0 \mathrm{c}$ & $0.0 \mathrm{c}$ & $0.0 \mathrm{c}$ & $0.0 \mathrm{c}$ \\
\hline 8. & $0.0 \mathrm{c}$ & $0.0 \mathrm{c}$ & $0.0 \mathrm{c}$ & $0.0 \mathrm{~b}$ & $0.0 \mathrm{c}$ & $0.0 \mathrm{c}$ & $0.0 \mathrm{c}$ & $0.0 \mathrm{c}$ \\
\hline$* \mathrm{CV}$ & 21.2 & 24.0 & 25.0 & 22.4 & 24.3 & 22.2 & 17.4 & 22.5 \\
\hline
\end{tabular}

Note. *Coefficient of variation.

Mean values followed by the same letter did not present significant differences (Tukey test, $\mathrm{p}<0.05$ ).

Treatments: 1. Control; 2. Boric acid (ba) + zinc sulfate (zs); 3. Copper hydroxide (coophi); 4. Coophi + boric acid + zinc sulfate; 5. Pyraclostrobin + epoxiconazole (pyepox); 6. Pyepox + coophi; 7. Pyepox + ba + zs; 8 . Pyepox + coophi + ba + zs. 


\section{Discussion}

Eight five percent of the treatment showed copper retention rates $>30 \%$ after $30 \mathrm{~mm}$ of artificial rain at $120 \mathrm{~min}$ after spraying the products. However, only $45 \%$ of the treatments remained with rates $>30 \%$ when the artificial rain was simulated at $480 \mathrm{~min}$ after application of the chemicals. Therefore, the treatments behaved differently regarding the drying time (120 $\mathrm{min}$ and $480 \mathrm{~min})$, between the application of chemicals and the artificial rain. Three treatments (copoxy $+0.1 \%$ adj, copoxy $+0.2 \%$ adj, and copoxy + mo $1.0 \%+0.2 \%$ adj) resulted in less than $30 \%$ of copper retained on leaf surface at $120 \mathrm{~min}$ after the $30 \mathrm{~mm}$ rain. Most treatments $(85 \%)$ remained with copper retention rates $>30 \%$ with the deposit drying time at $120 \mathrm{~min}$.

When the 20 treatments were allowed to dry for $480 \mathrm{~min}, 45 \%$ showed copper rates below $30 \%$, while $55 \%$ had $>30 \%$. These results suggest that copper retention rates vary depending on the concentrations of adj and mo that were used in the mix.

The treatments resulting in copper retention rates $>30 \%$ after $480 \mathrm{~min}$ of $\mathrm{dt}$ contained copoxy + mo at $0.5 \%$ and $0.75 \%$, regardless of the adj concentrations. Adding $1.0 \%$ mo, regardless of adj concentrations, did not lead to increase retention.

Five of the treatments that led to copper retention rates $>50 \%$ after $30 \mathrm{~mm}$ of artificial rain at 120 min after application of the chemicals consisted in copoxy with mo at $0.25 \%, 0.5 \%, 0.75 \%$ and $1.0 \%$, and mo + adj at $1.0 \%+0.1 \%$, respectively. However, with 480 min of drying time, only two treatments (copoxy with $0.75 \%$ mo and mo + adj $1.0 \%+0.1 \%$ ) led to retention rates $>30 \%$.

Evaluation of the different variables with the application of copoxy + mo + adj with dt of 120 min indicated that all treatments behaved similarly retarding AUDPC values and differed significantly from the control (no chemicals). The highest disease severity level observed in the control was $11.4 \%$, and the lowest $0.0 \%$, with copoxy $+0.5 \%$ mo $+0.05 \%$ adj. The CCLR control varied between $94.6 \%$ (copoxy $+0.05 \%$ adj) and $100 \%$ (copoxy $+0.5 \% \mathrm{mo}+0.05 \% \mathrm{adj}$ ) with dt of $120 \mathrm{~min}$. Regarding copper retention rates, copoxy $+0.75 \%$ mo led to the highest value, $55.2 \%$; other treatments did not differ significantly from each other and varied between $32.8 \%$ (copoxy $+0.5 \%$ mo $+0.1 \%$ adj) and $39.9 \%$ (copoxy $+0.75 \%$ mo $+0.05 \%$ adj).

Evaluation of the different variables with the application of copoxy added to mo and adj exposed to $30 \mathrm{~mm}$ of artificial rain with drying time of $480 \mathrm{~min}$ indicated that disease severity rates differed significantly from the control, but not between treatments. The control had the highest severity rates $(7.4 \%)$, and the lowest $(0.0 \%)$ was obtained with copoxy $+0.5 \%$ mo $+0.1 \%$ adj. After the drying time of $480 \mathrm{~min}$, disease severity varied between $0.0 \%$ and $2.4 \%$ for copoxy $+0.5 \%$ mo $+0.1 \%$ adj (most efficient treatment) and copoxy without mo or adj (least efficient treatments), respectively.

Studies on the effect of rain on the fungicide efficiency are scarce in the literature. Oliveira et al. (2002) and Töfoli et al. (2002) observed low persistence of mancozeb in the wheat (Triticum aestivum L.) and tomato (Lycopersicon esculentum Mill), respectively, exposed to artificial rain, with increased rates of CCLR when vegetable oil was mixed with the fungicide. These results reinforce the importance of adding mo for retention of the protective fungicide mancozeb.

The control of coffee leaf rust at 480 min after the rain simulation varied between $71.5 \%$ (copoxy) and $99.5 \%$ (copoxy $+0.5 \%$ mo $+0.10 \%$ adj). The treatments copoxy and copoxy $+0.05 \%$ adj did not differ significantly between themselves regarding rust severity; however, they did differ from the other treatments regarding rates of control of coffee leaf rust. Töfoli et al. (2002) reported that $30 \mathrm{~mm}$ of artificial rain $60 \mathrm{~min}$ and $120 \mathrm{~min}$ after spraying led to decreased efficiency of copoxy for disease control. Oliveira et al. (2002) did not find significant differences in copoxy treatments with or without $20 \mathrm{~mm}$ of weekly showers of rain, although there was a slightly better performance in the absence of rain. These authors also reported that they did not find significant differences in the incidence or severity of coffee rust in treatments regardless of the exposure to artificial rain, which indicates a good level of persistence of cupric fungicides. In our study, copoxy and copoxy $+0.05 \%$ adj were the least effective treatments for the CCLR. However, copoxy $+0.5 \%$ mo $+0.10 \%$ adj was the most efficient at dt of $480 \mathrm{~min}$. Copper retention rates with drying time of $480 \mathrm{~min}$ varied between $23.7 \%$ (copoxy + $0.5 \% \mathrm{mo}+$ adj $0.20 \%$ ) and $51.5 \%$ (copoxy $+0.75 \% \mathrm{mo}$ ).

Overall, the use of adj to the fungicide mix did not have a significant effect on the increase of copper retention by the leaf surface or the reduction of coffee rust severity. Similar results were reported by Jesus et al. (2015) where the application of coophi mixed to adj resulted in no significant differences in rust incidence.

The Pearson correlation coefficient showed that higher copper retention rates was positively and significantly correlated with higher rates of coffee leaf rust control, for both severity and AUDPC. 
In previous studies, copper retention by the leaf surface was higher when the concentration of mo in the cupric mixture was $0.3 \%$ (Oliveira et al., 2002). In the present study, the best results were obtained with the copoxy mixed with $0.75 \% \mathrm{mo}$, for copoxy applied at $3.0 \mathrm{~kg} \mathrm{ha}^{-1}$. Copper retention by the leaf surface is critical since the coffee leaf rust control is carried out during the rainy season. Therefore, with higher copper retention rates, as long as the distribution of drops on the leaf surface is uniform, the leaves will be protected until senescence since the copper ion does not decompose. Rain washing is the most critical factor removing fungicide deposits from leaves. Another consideration is that the copper ion is an essential micronutrient for coffee trees and causes a 'tonic effect' on leaves. Thus, the leaves do not fall prematurely and continue to photosynthesize and supply carbohydrates to the fruits of the coffee tree (Cunha et al., 2004).

The results showed that the adjuvant concentration in the fungicide mix with the wettable powder copoxy should not exceed $0.1 \%$. The function of adjuvant is to reduce the surface tension of spray droplets, leading to better spreading of the mixture on the leaf surface. At higher concentrations $(0.2 \%)$, the adj may cause higher fungicide flow on the leaf surfaces and, consequently, the deposits of the chemicals decrease (Gaion et al., 2015; Silva et al., 2008). Still according to Gaion et al. (2015), adj at higher concentrations (0.2\%) in the fungicide mix leads to a more homogeneous and thinner layer of the fungicide, after spraying, allowing the droplets to be spread with higher speed on the leaf surface, but also making them more easily removed by the rain. Costa et al. (2010) reported that when adjuvant was added to an insecticide mix, no significant effects were found on the retention of the product by the leaf surface, possibly due to the increased flow potential of the mix.

The success spraying chemical products for the coffee leaf rust control will depend on many factors including leaf surface conditions (smooth, waxy, presence of trichomes), weather factors (temperature, relative humidity, wind, sun, and rain), type of equipment, and spray nozzles (Silva et al., 2008). When the fungicide formulation is a wettable powder, and the leaf surface is waxy as in the present study, it is recommended to add mo and adj to the mix to increase the efficiency of the chemical. According to Rich (1954), the amount of sprayed chemical product that adheres to the leaf surface and the amount of product remaining on the leaf after rainfall is some of the main factors determining the amount of active residue on the leaf surface, for effective control of diseases. Therefore, for protective or residual fungicides, rain is considered the factor that most removes chemical deposits from the leaves. A single heavy rain removes more chemicals from the leaf surface than several weak showers of rain with the same volume.

The use of mineral oil and adjuvant in the fungicide mix may improve the action of some fungicides sensitive to rainfall, as it provides better tenacity to the leaf surface and especially under rainfall (Suheri \& Latin, 1991). However, the effects of adding an adj to the copoxy fungicide exposed to rainfall should be analyzed separately for each product and formulation and can vary depending on the leaf surface and pathogen type.

The treatments with pyepox before exposure to $30 \mathrm{~mm}$ of simulated rain, with drying time of zero, $30 \mathrm{~min}, 120$ $\mathrm{min}$, and $480 \mathrm{~min}$ were almost total effective for the CCLR. The simulation of rain at time zero after the spraying pyepox + ba + zs led to $0.9 \%$ and $26.2 \%$ of severity and AACPD, respectively; such rates of severity are considered to be very low, in comparison to the control and treatment with ba + zs. Adding the micronutrients ba and zs did not affect the action of the pyepox mix for the CCLR.

The application of ba + zs did not produce a result different from the control at time zero $30 \mathrm{~min}$ of td but did differ from the control after $120 \mathrm{~min}$ and $480 \mathrm{~min}$ of drying time. However, the rates of the disease were high at drying time of $120 \mathrm{~min}$ and $480 \mathrm{~min}$. When the copoxy was employed in the formulation of pyepox $+\mathrm{ba}+\mathrm{zs}$, CCLR was $100 \%$. The presence of copper in the mix adds a protective and residual effect to the pyepox formulation. The mixture of three active ingredients (triazol, a strobilurin, and cupric fungicide) is critical in the CCLR under field conditions because it difficult the emergence of resistant mutants in the population of $H$. vastatrix (Zambolim, 2016).

When considering cophi alone and mixed with ba and zs, after drying time of $30 \mathrm{~min}, 120 \mathrm{~min}$, and $480 \mathrm{~min}$, an almost control of coffee leaf rust was achieved, except at time zero. This demonstrates that, after copper deposits dried on the leaf surface (30 min after spraying), the action of the ion provided effective control in the inhibition, germination, and growth of the germ tube in the pathogen uredospores. All sources of copper, whether hydroxides, oxides, oxychlorides, and sulfates, when applied preventively, are efficient in the coffee leaf rust control (Souza et al., 2011; Zambolim, 2016). Oliveira et al. (2002) showed that the CCLR by applying cophi, provided adequate control of the disease after $20 \mathrm{~mm}$ of rain, with a low incidence around $6 \%$ to $10 \%$, 60 days after spraying.

Rainy seasons are essential factors to consider for the coffee leaf rust control. In Brazil, they start in October/November and ends in March/April; while in Central America, they are between August and 
December/January. In Central America, rainfall rates are higher than $1,500 \mathrm{~mm}$ and can reach 2,500 $\mathrm{mm}$ per year. In practice, the recommendation for the coffee leaf rust control, if a cupric fungicide is adopted, is to perform the spraying from November to March/April. If a systemic fungicide is used, alone or with strobilurins, the spraying start should be based on the disease incidence (Silva-Acuña et al., 1992; Souza et al., 2011; Honorato Júnior et al., 2015a; Honorato Júnior et al., 2015b; Zambolim, 2016). However, the choice between a cupric fungicide and triazol + strobilurin requires the observation of date and time of application. Fungicide applications should not be made over wet leaves, as the products will not adhere to the leaf surface.

The treatment that was not affected by $30 \mathrm{~mm}$ of rain giving the highest percent of copper retention resulting in $>97 \%$ of coffee leaf rust control, was copper oxychloride $+0.75 \%$ mineral oil, both at 180 and $480 \mathrm{~min}$, respectively of drying time; pyraclostrobin + epoxiconazol alone or mixed with copper hidroxide also was not affected by the rain. The control of coffee leaf rust by this treatment was $100 \%$ of the disease after 30,120 , and $480 \mathrm{~min}$, respectively of spraying. These results are in according to the findings by several other authors (Costa et al., 2007; Souza et al., 2011; Honorato Júnior et al., 2015b; Capucho et al., 2013b).

\section{Conclusion}

In conclusion, the efficiency of the copper oxychloride for the control of coffee leaf rust varies with the concentration of the adjuvant and mineral oil added to the fungicide mix. Except for copper oxychloride treatment alone and copper oxychloride associated with $0.05 \%$ adjuvant, all other treatments containing mineal oil and adjuvant improved control of coffee leaf rust. The most efficient treatment was copper oxychloride combined with $0.5 \%$ mineral oil $+0.1 \%$ adjuvant. The triazole + strobilurin formulation provided effective control of coffee leaf rust even at time zero of the rain simulation. For copper hidroxide, the time elapsed between the rain should be higher than $30 \mathrm{~min}$, for complete control of coffee leaf rust. The mixture of copper hidroxide with triazol + strobilurin + boric acid + zinc sulfate was effective in the control of coffee leaf rust, even after the application of simulated rain, soon after spraying the chemicals.

\section{Acknowledgements}

The first author thanks the University of Costa Rica for the scholarship to take graduate course.

\section{References}

AGROFIT. (2019). Ministério da Agricultura, Pecuária e Abastecimento. Brasília, Distrito Federal.

Antuniassi. U. R., et al. (2005). Desempenho de sistema de aplicação terrestre para controle da ferrugem de soja (pp. 217-218). Reunião de pesquisa de soja da região central do Brasil, 27, 2005, Cornélio Procópio. Resumos... Londrina: Embrapa Soja.

Avelino, J., Cristancho, M., Georgiou, S., Imbach, P., Aguilar, L., Bornemann, G., ... Morales, C. (2015). The coffee rust crises in Colombia and Central America (2008-2013): Impacts, plausible causes and proposed solutions. Food Sec.

Bartlett, D. W., Clough, J. M., Godwin, J. R., Hall, A. A., Hamer, M., \& Parr-Dobrzanski, B. (2002). Review: The strobilurin fungicides. Pest Management Science, 58, 649-662. https://doi.org/10.1002/ps.520

Bonelli, M. A. P. O., et al. (2005). Desempenho de sistemas de aplicação aérea para controle de ferrugem da soja (pp. 119-120). Reunião de pesquisa de soja da região central do Brasil, 27, Cornélio Procópio. Resumos... Londrina: Embrapa Soja.

Cabras, P., Angioni, A., Garau, V. L., Melis, M., Pirisi, F. M., Cabitza, F., \& Pala, M. (2001). The effect of simulated rain on folpet and mancozeb residues on grapes and wine leaves. Journal of environmental Science and Health, 36, 609-618. https://doi.org/10.1081/PFC-100106189

Capucho, A. S., Zambolim, L., Cabral, P. G. C., Zambolim, E. M., \& Caixeta, E. T. (2013a). Climate favourability to leaf rust in Conilon coffee. Australasian Plant Pathology, 24, 511-514.

Capucho, A. S., Zambolim, L., \& Milagres, N. (2013b). Chemical control of coffee leaf rust in Coffea canephora cv. conilon. Australasian Plant Pathology, 42, 667-673.

Chalfoun, S. M., \& De Carvalho, V. L. (1999). Controle químico da ferrugem (Hemileia vastatrix Berk. \& Br.) do cafeeiro através de diferentes esquemas de aplicação. Pesquisa Agropecuária Brasileira, 34, 363-367. https://doi.org/10.1590/S0100-204X1999000300006

Campbell, C. L., \& Madden, L. V. (1990). Introduction to plant disease epidemiology (p. 655). New York: John Wiley \& Sons. 
Chaves, M. G., Cruz Filho, J., Carvalho, M. G., Matsuoka, K., Coelho, D. T., \& Shimoya, C. A. (1970). Ferrugem do cafeeiro (Hemileia vastatrix Berk. \& Br). Revisão de literatura com observações e comentários sobre a enfermidade no Brasil. Seiva, 30,175.

Christofoletti, J. C. (1999). Considerações sobre a deriva nas pulverizações agrícolas e seu controle (p. 15). São Paulo: Teejet South América.

Costa, M. J. N., Zambolim, L., \& Rodrigues, F. R. (2007). Avaliação de produtos alternativos no controle da ferrugem do cafeeiro. Fitopatologia Brasileira, 32, 147-152. https://doi.org/10.1590/S0100-415820070002 00010

Costa, M. F., Alandia, R. A., Carvalho, G. F. G., \& Baggio, M. V. (2010). Determinação de área foliar e retenção de liquido por folhas de café em pulverização a alto volume. Nucleus, 7, 277-284.

Cunha, R., Guimarães, A., \& Chalfoun, S. (2004). Controle químico da ferrugem do cafeeiro (Coffea arabica L.) e seus efeitos na produção e preservação do enfolhamento. Ciência e Agrotecnologia, 28, 990-996. https://doi.org/10.1590/S1413-70542004000500004

Debortoli, M. (2008). Efeito do rainfastness e adjuvantes na aplicação de fungicidas foliares em cultivos de soja. Universidade Federal de Santa Maria (UFSM-RS), Santa Maria, RS, Brazil.

Di Rienzo J. A., Casanoves, F., Balzarini, M. G., Gonzalez, L., Tablada, M., \& Robledo, C. W. (2015). InfoStat versión 2015. Grupo InfoStat, FCA, Universidad Nacional de Córdoba, Argentina. Retrieved from http://www.infostat.com.ar

Eskes, A. B. (1982). The use of leaf disk inoculations in assessing resistance to coffee leaf rust (Hemileia vastatrix). Netherlands Journal of Plant Pathology, 88, 127-141. https://doi.org/10.1007/BF01977270

Fife, J. P., \& Nokes, S. E. (2002). Evaluation of the effect of rainfall intensity and duration on the persistence of chlorothalonil on processing tomato foliage. Crop Protection, 21, 733-740. https://doi.org/10.1016/S02612194(02)00030-3

Gaion, L., Lasmar, O., \& Costa Ferreira, M. (2015). Efeito da adição de adjuvantes a calda com fungicida em plantas de citros sob chuva artificial. Citrus Research \& Technology, 36(2). https://doi.org/10.4322/crt08816

Garcia, A. (1999). A resistência dos fungos como consequência da utilização de fungicidas sistêmicos: Mecanismos de resistência (p. 28). Monitoramento e estratégias anti-resistência. Porto Velho: Embrapa Rondônia.

Green. J. M. (2001). Factors that influence adjuvant performance (pp. 179-190). International symposium on adjuvants for agrochemicals, 6, Amsterdam. Proceedings... Amsterdam: ISAA Foundation.

Honorato Junior, J., Zambolim, L., Aucique-Perez, C. E., Resende, R. S., \& Rodrigues, F. A. (2015a). Photosynthetic and antioxidative alterations in coffee leaves caused by epoxiconazole and pyraclostrobin sprays and Hemileia vastatrix infection. Pesticide Biochemistry and Physiology, 123, 31-39.

Honorato Junior, J., Zambolim, L., Lopes, U. N., Lopes, U. P., Da Silva, H., \& Duarte, S. (2015b). DMI and QoI fungicides for the control of coffee leaf rust. Australasian Plant Pathology, 44(5).

Jesus, F. F., Leite, J. F. B., Goulart, R. R., \& Miranda, G. R. B. (2015). Efeito de adjuvantes associados ao hidróxido de cobre no controle da ferrugem do cafeeiro (Coffea arabica L.). $7^{\mathrm{a}}$ Jornada Cientifica $\mathrm{e}$ Tecnologica do IFSULDEMINAS, 40 Simpósio de Pós Graduacão.

Koller, W., \& Scheinplug, H. (1987). Fungal resistance to sterol biosynthesis inhibitors: A new challenge. Plant Disease, 71, 1066-1074. https://doi.org/10.1094/PD-71-1066

Mariotto, P. R., Figueiredo, P., Silveira, A. P., Júnior, G., Arruda, H. V., Lopes, H.,... Oliveira Filho, N. L. (1976). Estudos sobre o controle químico da ferrugem do cafeeiro (Hemileia vastatrix Berk \& Br.) e seus efeitos na produção. nas condições do estado de São Paulo. O Biológico, 45, 165-174.

McCook, S. (2006). Global rust belt: Hemileia vastatrix and the ecological integration of word coffee production since 1850. Journal of Global History, 177-195. https://doi.org/10.1017/S174002280600012X

Oliveira, S. H. F., Santos, J. M. F., \& Guzzo, S. D. (2002). Efeito da chuva sobre a tenacidade e eficiência de fungicidas cúpricos associados ao óleo vegetal no controle da ferrugem do cafeeiro. Fitopatologia Brasileira, 27, 581-585. https://doi.org/10.1590/S0100-41582002000600004 
Pereira, G. A. M., Barcellos, J. R., Gonçalves, V. A., \& Silva, A. A. (2017). Clomazone Leaching Estimate in soil Colimns Using the Biological Method. Sociedade Brasileira de Ciências das Plantas Daninhas. Planta Daninha, 35.

Reynolds, K. L., Reilly, C. C., \& Hotchkiss, M. W. (1994). Removal of fentin hydroxide from pecan seedlings by simulated rain. Plant Disease, 78, 857-860. https://doi.org/10.1094/PD-78-0857

Rich, S. (1954). Dinamics of deposition and tenacity of fungicides. Phytopathology, 44, 203-213.

Santos, J. M. F, Oliveira, S. H. F, Domingues, R. J., \& Guzzo, S. D. (2002). Avaliação da eficácia de fungicidas sistêmicos no controle da ferrugem (Hemileia vastatrix Berk. \& Br.) do cafeeiro. sob chuva simulada. Arq. Inst. Biol., 69, 45-49.

Silva, A., Leite, M., \& Ferreira, M. (2008). Estimativa da área foliar e capacidade de retenção de calda fitossanitária em cafeeiro. Biosci. J. Uberlandia, 24, 66-73.

Silva-Acuña, R., Zambolim, L.,Vale, F. X. R., Chaves, G. M., \& Pereira, A. A. (1992). Época da primeira aplicação de fungicida baseado no nível de inicial de incidênciapara o controle da ferrugem do cafeeiro. Fitopatologia Brasileira, 17, 36-41.

Souza, A. F., Zambolim, L., Jesus Júnior, V. C., \& Cecon, P. R. (2011). Chemical approaches to manage coffee leaf rust in drip irrigated trees. Australasian Plant Pathol, 40, 293-300. https://doi.org/10.1007/s13313011-0046-x

Staub, T., \& Sozzi, D. (1984). Fungicide resistance: A continuing challenge. Plant Disease, 68, 1026-1031. https://doi.org/10.1094/PD-68-1026

Stefanello, T. M., Balardin, R. S., Minuzzi, S. G., Favera, D. D., Marques, L. N., Pezzini, D. T., \& Ebone, E. (2016). Effect of the interaction between fungicide application time and rainfall simulation interval on Asian Soybean Rust control effectiveness. Ciências Agrárias, 37(6), 3881-3892. https://doi.org/10.5433/ 1679-0359.2016v37n6p3881

Suheri, B., \& Latin, C. (1991). Retention of fungicides for control of Alternaria leaf blight of muskmelon under greenhouse conditions. Plant Disease, 1013-1015. https://doi.org/10.1094/PD-75-1013

Töfoli, J. M., Oliveira, S. H. F., Domingues, R. J., Santos, J. M. F., \& Martins, E. M. F. (2002). Desempenho de azoxystrobin no controle da ferrugem do cafeeiro sob condições de chuva induzida. Arquivos do Instituto Biologico, 69, 93-96

Tracker, J. R. M., \& Young, R. D. F. (1999). Effects of six adjuvants on the rainfastness of chlorpyrifos formulated as an emulsifiable concentrate. Extended Summaries: IUPAC Conference-Pesticide Science, 55, 198-200.

Tu, M., \& Randall, J. M. (2003). Adjuvants. Weed control methods handbook (pp. 1-24). The Nature Conservancy.

Underwood, A. K. (2000). Adjuvant trends for the new millennium. Weed Technology, 14, 765-772. https://doi.org/ 10.1614/0890-037X(2000)014[0765:ATFTNM]2.0.CO;2

Wang, C. J., \& Liu, Z. Q. (2007). Foliar uptake of pesticides: Present status and future challenge. Pesticide Biochem. and Physiology, 87, 1-8. https://doi.org/10.1016/j.pestbp.2006.04.004

Witt, J. M. (2001). Agricultural spray adjuvants. Ithaca, NY: Cornell University. Retrieved from http://pmep.cce. cornell.edu/facts-slides-self/facts/genpeapp-adjuvants.html

Zambolim, L. (2019). Resistência de fungos a fungicidas. In L. Zambolim (Ed.), O que engenheiros-agrônomos devem saber para recomendar corretamente os produtos fitossanitários (pp. 372-427). Universidade Federal de Viçosa, Viçosa, Minas Gerais.

Zambolim, L. (2016). Current status and management of coffee leaf rust in Brazil. Trop. Plant Pathology, 41, 1-8. https://doi.org/10.1007/s40858-016-0065-9

Zambolim, L., \& Chaves, G. M. (1974). Efeito de baixas temperaturas e do binômio temperatura-umidade relativa sobre a viabilidade dos urediosporos de Hemileia vastatrix Berk. \& Br. e Uromyces phaseolitypica Arth. Experientiae, 17, 151-184.

Zambolim, L., Picanço, M., Silva, A. A., Ferreira, L., \& Jesus Junior, W. C. (2008). Produtos Fitosanitarios (fungicida, inseticida, acaricida e herbicidas) (pp. 263-348). Viçosa, Minas Gerais: Editora UFV. 


\section{Copyrights}

Copyright for this article is retained by the author(s), with first publication rights granted to the journal.

This is an open-access article distributed under the terms and conditions of the Creative Commons Attribution license (http://creativecommons.org/licenses/by/4.0/). 